\title{
EFFECT OF CARBAMIDE PEROXIDE-BASED BLEACHING AGENTS CONTAINING FLUORIDE OR CALCIUM ON TENSILE STRENGTH OF HUMAN ENAMEL
}

\author{
EFEITO DE AGENTES CLAREADORES À BASE DE PERÓXIDO DE CARBAMIDA \\ CONTENDO FLUORETO E CÁLCIO NA RESISTÊNCIA À TRAÇÃO DO ESMALTE HUMANO
}

Marcelo GIANNINI ${ }^{1}$, Alessandra Peres SILVA ${ }^{2}$, Vanessa CAVALLI ${ }^{3}$, Adriana Franco PAES LEME ${ }^{4}$

1- Associate Professor, Department of Restorative Dentistry, Piracicaba Dental School, Campinas State University, Piracicaba, SP, Brazil.

2- Undergraduate student, Piracicaba Dental School, Campinas State University, Piracicaba, SP, Brazil.

3- Graduate student (Doctor degree), Department of Restorative Dentistry, Piracicaba Dental School, Campinas State University, Piracicaba, SP, Brazil.

4- Graduate student (Doctor degree), Department of Physiological Sciences, Piracicaba Dental School, University of Campinas, Piracicaba, SP, Brazil.

Corresponding address: Prof. Dr. Marcelo Giannini - Department of Restorative Dentistry - Operative Dentistry Section Piracicaba Dental School - University of Campinas - Av. Limeira, 901 - Piracicaba - SP - Brazil - Cep.: 13414-018

Phone: 19-34125340 - Fax: 19-34125218 - e-mail: giannini@fop.unicamp.br

Received: February 14, 2005 - Modification: October 20, 2005 - Accepted: February 14, 2006

\begin{abstract}
$O$

bjective: The aim of this study was to evaluate the effects of carbamide peroxide-based bleaching agents (CPG) containing fluoride (CF) or calcium (CCa) on the ultimate tensile strength of enamel (UTS). Method: A “cube-like" resin composite structure was built-up on the occlusal surface of twenty-two sound third molars to facilitate specimen preparation for the micro-tensile test. The restored teeth were serially sectioned in buccal-lingual direction in slices with approximate $0.7 \mathrm{~mm}$ thickness. Each slice was trimmed with a fine diamond bur to reduce the buccal, internal slope enamel of the cusps to a dumb-bell shape with a cross-sectional area at the "neck" of less than 0.5 mm². The samples were randomly divided into 12 groups $(\mathrm{n}=11)$. The control groups were not submitted to the bleaching regimen. Specimens were treated with $10 \%$ CPG gel or with $10 \%$ CPG formulations containing CF ( $0.2 \%$ and $0.5 \%)$ or CCa (0.05\% and $0.2 \%)$. Bleached groups received the application of the $10 \%$ CPGs for 6 hours/day at $37^{\circ} \mathrm{C}$, during 14 consecutive days and were stored in artificial saliva (AS) or $100 \%$ relative humidity $(\mathrm{RH})$ among each application. After bleaching, specimens were tested with the microtensile method at $0.5 \mathrm{~mm} / \mathrm{min}$. Data were analyzed by two-way ANOVA and Tukey test (5\%). Results: No significant difference was observed between groups stored in AS or RH. Specimens treated with CF or CCa presented similar UTS as unbleached control groups. Conclusion: Either 10\% CPG formulations containing CF or CCa can preserve the UTS after bleaching regimen.

Uniterms: Hydrogen peroxide; Calcium; Sodium fluoride; Dental enamel; Tensile strength.
\end{abstract}

\begin{abstract}
RESUMO
Objet bjetivo: O propósito deste estudo foi avaliar os efeitos de agents clareadores à base de peróxido de carbamida (CPG) contendo fluoreto (CF) e cálcio (CCa) na resistência à tração do esmalte (UTS). Método: Um bloco de resina composta foi confeccionada na superfície oclusal de vinte e dois terceiros molars hígidos para facilitar a preparação dos espécimes para o teste de micro-tração. Os dentes restaurados foram seccionados com disco diamantado no sentido vestíbulo-lingual em fatias de aproximadamente $0,7 \mathrm{~mm}$ de espessura. Com uma ponta diamantada, foi realizada uma constrição na região de esmalte da vertente oclusal interna. Os espécimes apresentaram aproximadamente 0,5 $\mathrm{mm}^{2}$ de área na secção transversal da região de constrição e foram divididos em 12 grupos (n=11). Os grupos controles não foram submetidos ao regime clareador e os experimentais foram tratados com gel de CPG $10 \%$ ou com formulações de CPG $10 \%$ contendo CF (0,2\% e $0,5 \%)$ ou CCa (0,05\% e 0,2\%). Os grupos clareadores receberam a aplicação dos CPGs por 6 horas/dia a $37^{\circ} \mathrm{C}$, durante 14 dias consecutivos e foram armazenados em saliva artificial (AS) ou em umidade relativa 100\% (RH), entre as aplicações do gel clareador. Após o clareamento, os espécimes foram testados através do método de micro-tração $(0,5 \mathrm{~mm} / \mathrm{min})$. Os dados foram analisados pela ANOVA (2 fatores) e teste Tukey (5\%). Resultados: Nenhuma diferença foi observada entre os grupos armazenados em AS ou RH. Os espécimes tratados com CPG com CF ou Cca apresentaram similar UTS aos grupos controles não clareados. Conclusão: Ambos CPGs 10\% CF or CCa não alteraram a UTS após o tratamento clareador.
\end{abstract}

Unitermos: Peróxido de hidrogênio; Cálcio; Fluoreto de sódio; Esmalte dentário; Resistência à tração. 


\section{INTRODUCTION}

Previous bleaching methods were more aggressive due to application of 30 to $35 \%$ hydrogen peroxide in combination with a heat lamp or a heating element, microabrasion and etching with $37 \%$ phosphoric acid. Home bleaching techniques using $10 \%$ carbamide peroxide gel in a mouthguard have been considered less invasive, safe for soft tissues and an effective method to bleach vital teeth ${ }^{13}$. Since contemporary concepts in Esthetic Dentistry recommend less invasive techniques without tooth damage, the use of home bleaching techniques has become popular for whitening stained and discolored teeth ${ }^{14,18}$.

The concerning adverse effects are due to the widespread acceptance between dentist and patients. There is no agreement about the effects of bleaching on enamel, since scanning electron microscopy investigations of bleached enamel surfaces have shown little or no topographic alterations ${ }^{17,22}$, while surface changes after carbamide peroxide bleaching have been reported. The alterations include increased porosity, pitting, erosion and demineralization of enamel prisms periphery ${ }^{1,9,12,15,23,27}$. Moreover, chemical composition, mechanical and physical properties of bleached human enamel have also

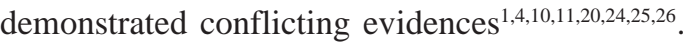

A study evaluating bleached enamel with carbamide peroxide solution followed by fluoride treatment and enamel did not show resistance to demineralization ${ }^{6}$. However, if ions were added during bleaching and ionic exchange, maybe they could be uptaken and increase enamel resistance to demineralization. As both fluoride and calcium ions would increase the saturation of bleaching agent gel, a lower mineral loss would occur during bleaching. Thus, bleaching gel compositions with addition of fluoride or calcium could reduce or overcome the bleaching adverse effects.

The aim of this study was to test the null hypothesis that the ultimate tensile strength (UTS) of enamel is not altered when exposed to carbamide peroxide-based bleaching agents containing fluoride or calcium. Additionally, the tested specimens were analyzed under scanning electron microscope (SEM) to evaluate the features of fractured surfaces.

\section{MATERIALS AND METHODS}

Twenty-two sound, extracted human third molars, stored in $0.1 \%$ thymol solution for no longer than two weeks after extraction were used in this study. The teeth were obtained after informed consent by the patients and under the protocol (045/2003) that was analyzed and approved by the Ethical Research Committee of Piracicaba Dental School / UNICAMP, Brazil. The teeth were cleaned of gross debris and placed in relative humidity before beginning the experiment.

Enamel occlusal surfaces were air-abraded with aluminum oxide (50 mm), etched with 35\% phosphoric acid for $30 \mathrm{~s}$, air dried and bonded with Single Bond adhesive system (3M ESPE, St. Paul, MN, USA). Bonded surfaces received three layers of TPH Spectrum resin composite (Dentsply Caulk, Milford, DE, USA) to build up a "cube-like" crown of approximately $6.0 \mathrm{~mm}$ in height (Figure 1a). Each resin layer was light cured for $40 \mathrm{~s}$ with a XL 3000 light-curing unit (3M ESPE, St. Paul, MN, USA) and the restored teeth were stored in relative humidity at $37^{\circ} \mathrm{C}$. After $24 \mathrm{~h}$, the crowns were vertically, serially sectioned into $0.7-\mathrm{mm}$ thick slabs with a diamond saw (Isomet 1000, Buehler Ltd., Lake Bluff, IL, USA) under water lubrication (Figure 1b).

Each slab (Figure 1c) was trimmed from both sides with a fine diamond bur (1040, KG Sorensen Ind. e Com. Ltda, Barueri, SP, Brazil) (Figure 1d) under water lubrication to conform the specimen to an "hour-glass" shape and reduce the cross-sectional area of the "neck" to approximately $0.5 \mathrm{~mm}^{2}$ (Figure 1e). Specimens were prepared from the enamel located at the internal slope of the buccal cusps of teeth ${ }^{7}$. From each restored teeth, six slabs were selected based on

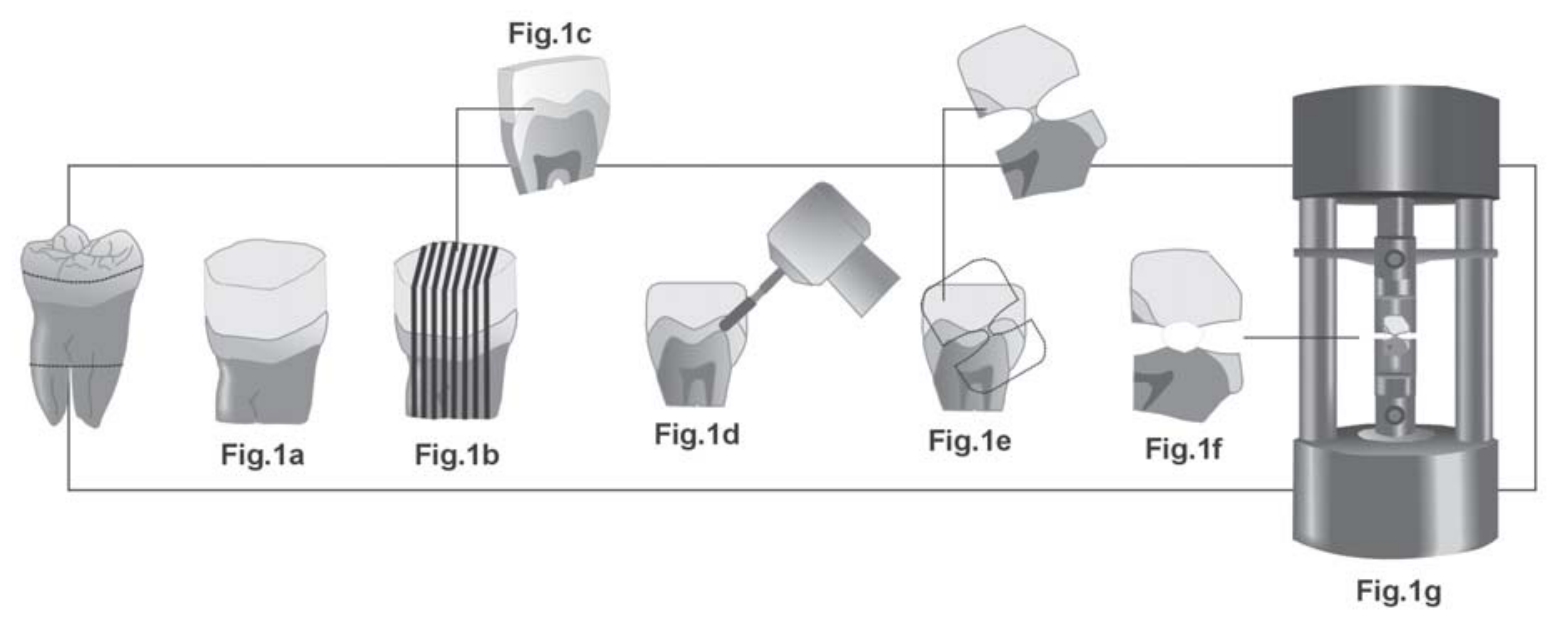

FIGURE 1- Schematic representation of specimen preparation (1a- composite placed over enamel oclusal surface to facilitate the microtensile bond strength test; $1 \mathrm{~b}$ - tooth vertically sectioned into some slabs; $1 \mathrm{c}-0.7-\mathrm{mm}$ thick slab; $1 \mathrm{~d}$ - slabs were trimmed with a fine diamond bur; 1e- specimen prepared after trimming and the enamel structure to be tested was prepared from the enamel located at the internal slope of the buccal cusp; 1f- bleaching gel applied on trimmed enamel area; $1 \mathrm{~g}$ - treated specimen fixed to the "grips" of microtensile test device) 
their integrity after trimming, obtaining one hundred thirtytwo trimmed specimens. Those presenting cracks or defects were discarded after examination under 40x magnification.

\section{Bleaching procedures}

Specimens were randomly assigned to 12 groups $(\mathrm{n}=$ 11) as follows:

Group 1 and 7- Control, no bleaching treatment.

Group 2 and 8- Bleaching with 10\% carbamide peroxide.

Group 3 and 9- Bleaching with 10\% carbamide peroxide with $0.2 \%$ fluoride.

Group 4 and 10-Bleaching with 10\% carbamide peroxide with $0.5 \%$ fluoride.

Group 5 and 11- Bleaching with 10\% carbamide peroxide with $0.05 \%$ calcium.

Group 6 and 12- Bleaching with 10\% carbamide peroxide with $0.2 \%$ calcium.

Unbleached control groups were kept in artificial saliva (group 1) or in $100 \%$ relative humidity (group 7 ) at $37^{\circ} \mathrm{C}$ for the same time period of bleached groups. For treated groups, the trimmed enamel area was daily exposed to a mixture of $0.1 \mathrm{~mL}$ of the respective bleaching agent with $0.05 \mathrm{~mL}$ of artificial saliva $^{8}$ for 6 hours, during 14 consecutive days (Figure 1f). During the bleaching period, the specimens were placed in $100 \%$ relative humidity at $37^{\circ} \mathrm{C}$. After daily bleaching, the specimens were thoroughly rinsed with deionized water for 10 seconds and stored in $0.5 \mathrm{~mL}$ of artificial saliva at $37^{\circ} \mathrm{C}$ (groups 2 to 6 ) or in $100 \%$ relative humidity at $37^{\circ} \mathrm{C}$ (groups 8 to 12 ), until the next daily bleaching treatment. After the end of the bleaching regimen (14 $4^{\text {th }}$ day), specimens were rinsed and stored in relative humidity for $24 \mathrm{~h}$ at $37^{\circ} \mathrm{C}$ before testing.

\section{Testing}

Each specimen was fixed to the "grips" of a microtensile testing device with cyanoacrylate glue (Zapit, DVA, Corona, CA, USA) and tested in tension in a universal testing machine (4411, Instron Co., Canton, MA, USA) at $0.5 \mathrm{~mm} /$ min until failure (Figure 1g). After testing, specimens were carefully removed from the fixtures with a scalpel blade and the cross-sectional area at the site of fracture measured to the nearest $0.01 \mathrm{~mm}$ with a digital caliper (727-6/150, Starret, SP, Brazil) to calculate UTS expressed in MPa. Data were analyzed by two-way (bleaching treatment and storage factors) analysis of variance (ANOVA) and Tukey test at a $=0.05$.

\section{Microscopy}

Tested specimens were allowed to dry in an oven overnight and the fractured edges were sputter-coated with gold (MED 010, Balzers, Balzer, Leichtenstein). SEM (VP 435, Leo, Cambridge, England) photomicrographs of a representative area of the fracture surfaces were taken at $10,000 X$.

\section{RESULTS}

UTS means for experimental groups are presented in Table 1. Two-way ANOVA detected a statistically significant difference among bleaching materials ( $p=0.00002$ ), no significant difference between specimens stored in artificial saliva and relative humidity ( $\mathrm{p}=0.738$ ) and failed to identify any factor interactions (bleaching treatment and storage) ( $p$ $=0.542$ ).

Tukey test showed that unbleached control groups exhibited higher UTS than groups treated with gel formulations containing only $10 \%$ carbamide peroxide. Experimental bleaching agents containing fluoride and calcium exhibited similar UTS to unbleached control groups. Bleaching agents containing 10\% carbamide peroxide with $0.05 \%$ calcium resulted in similar tensile strength for all experimental and control groups tested.

SEM observations of fractured specimens showed that the fracture mode of unbleached and bleached groups were not similar. Unbleached fractured enamel (groups 1 and 7) depicted a compact structure with no clear porosity, showing a typical fractured surface of sound and intact enamel (Figure 2). Bleached fractured enamel with $10 \%$ carbamide peroxide (groups 2 and 8) presented prisms dislodged in a cone-like shape and their fractured ends seemed porous (Figure 3). The porosities at prism fractured ends were reduced using carbamide peroxide-based bleaching agents containing

TABLE 1- Tensile strength of enamel (MPa, mean \pm SD), according to the treatments and storage $(n=11)$

\begin{tabular}{|c|c|c|c|c|}
\hline Groups & Artificial Saliva & & Relative Humidity & Tukey test (5\%) \\
\hline Control (unbleached) & $36.4 \pm 2.45$ & NS & $34.5 \pm 3.41$ & $A$ \\
\hline $10 \% \mathrm{CP}$ & $23.2 \pm 6.50$ & NS & $24.8 \pm 2.98$ & B \\
\hline $10 \% \mathrm{CP}+0.05 \mathrm{Ca}^{2+}$ & $27.68 \pm 6.08$ & NS & $30.6 \pm 4.85$ & $A B$ \\
\hline $10 \% \mathrm{CP}+0.2 \mathrm{Ca}^{2+}$ & $35.6 \pm 5.08$ & NS & $32.0 \pm 8.54$ & $A$ \\
\hline $10 \% \mathrm{CP}+0.2 \mathrm{~F}^{-}$ & $29.8 \pm 5.95$ & NS & $31.4 \pm 4.20$ & $A$ \\
\hline $10 \% \mathrm{CP}+0.5 \mathrm{~F}^{-}$ & $30.6 \pm 5.89$ & NS & $32.1 \pm 6.13$ & $A$ \\
\hline
\end{tabular}

CP 10\% - 10\% Carbamide Peroxide.

NS- no statistically significant difference between storages. 
fluoride or calcium (Figures 4 and 5).

\section{DISCUSSION}

The addition of calcium or fluoride in the composition of whitening materials is an alternative to reduce the adverse effects promoted by peroxides during bleaching. Studies have shown that enamel alterations are not limited only to the surface and they are also associated with loss of microhardness and strength, inorganic and organic changes $1,2,10,11,21,23,25,26$. Thus, the purpose of formulation of bleaching agent with addition of fluoride and calcium ions would be to increase the saturation of gel, reducing mineral loss and increasing enamel resistance to demineralization caused by peroxides.

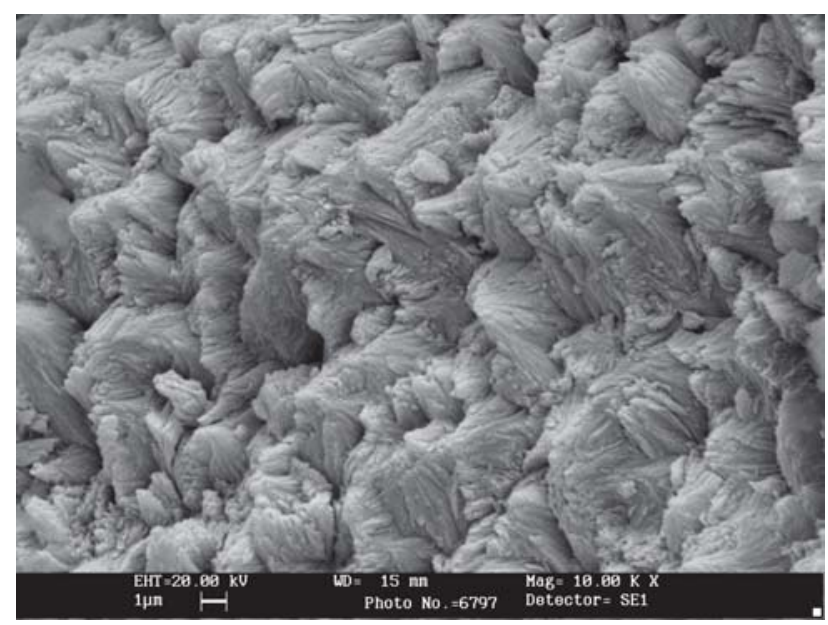

FIGURE 2- Fractured enamel surface of unbleached specimens stored in artificial saliva. Cone-like and protruding prisms indicate a typical fracture pattern that occurs transversally to prismatic orientation of the sound enamel

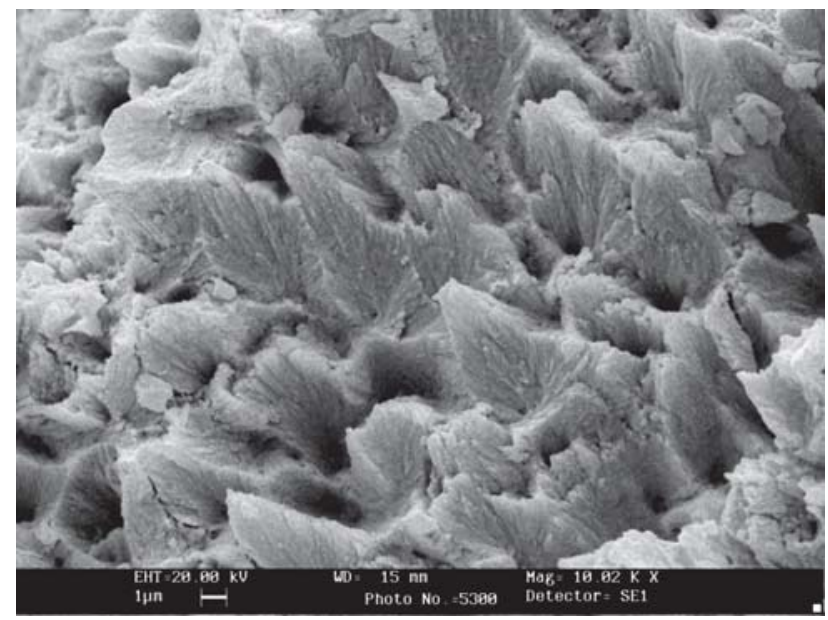

FIGURE 4- Fractured enamel surface of bleached specimens with $10 \%$ carbamide peroxide containing $0.5 \%$ fluoride stored in artificial saliva. The porosities at ends of fractured prisms were reduced
The gel application composed by only $10 \%$ carbamide peroxide (groups 2 and 8) caused significant decrease in the UTS of enamel when compared with untreated groups. The reduction was about $30 \%$, which was close to that reported by Seghi and Denry ${ }^{26}$ (1992) and Cavalli et al. ${ }^{10}$ (2004). Enamel alterations previously described, such as porosites and surface erosion, can be created along the exposed area, which may have acted as stress raisers during testing resulting in premature failures. The shape of specimens in this study formed four ground enamel subsurfaces that are all within $0.35 \mathrm{~mm}$ of the center and can increase the changes and damage to enamel promoted by whitening products. Clinically, bleaching agents are applied on sound and intact surfaces. However, as enamel presents high permeability to hydrogen peroxide ${ }^{19}$, it can penetrate through enamel and dentin due to its low molecular weigth ${ }^{3,16}$ and the entire

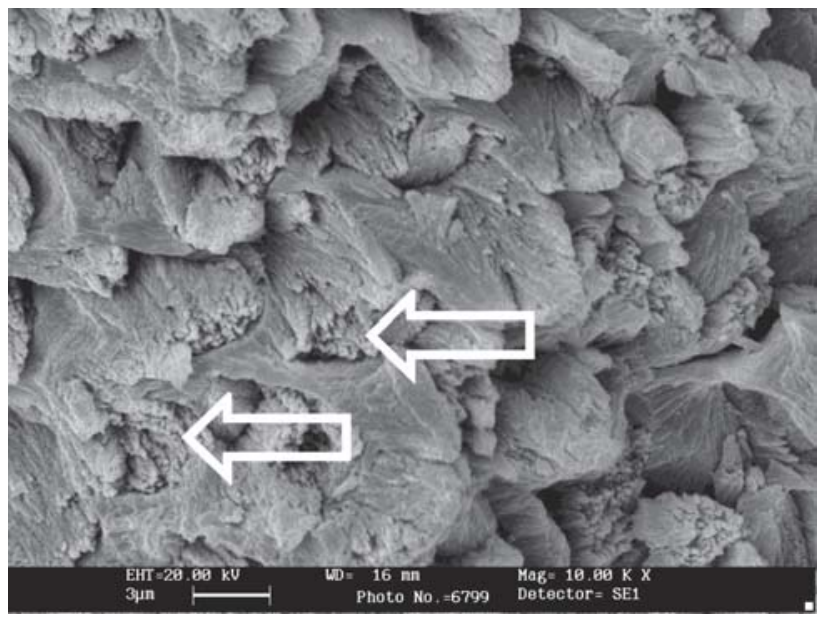

FIGURE 3- Fractured enamel surface of bleached specimens with $10 \%$ carbamide peroxide stored in artificial saliva. Porosities are seen on the surface of transversally fractured prisms (arrowheads)

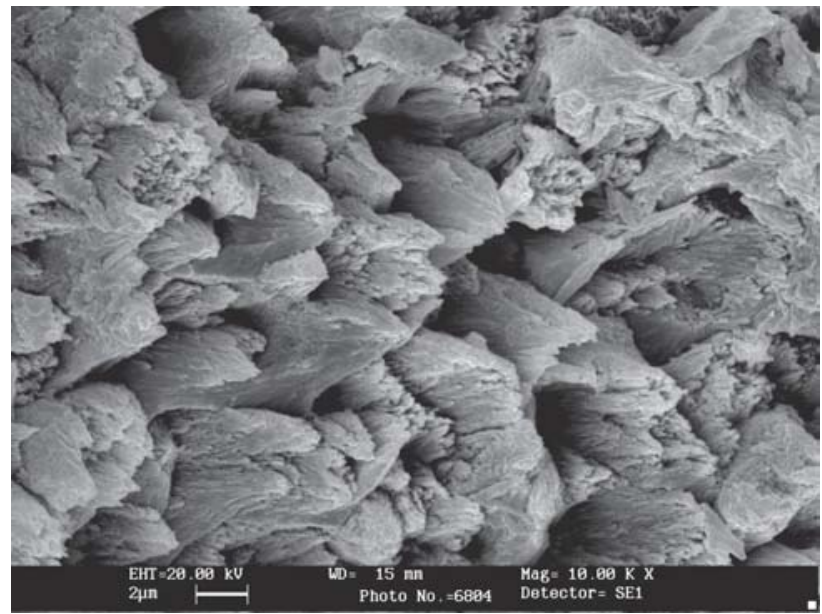

FIGURE 5- Fractured enamel surface of bleached specimens with $10 \%$ carbamide peroxide containing $0.05 \%$ calcium stored in relative humidity. The general appearance was that enamel seemed more porous than the unbleached specimens, but less than those bleached with only $10 \%$ carbamide peroxide 
thickness of the specimen could be modified by prolonged treatments.

Unbleached fractured enamel showed a typical, transversal fracture pattern of enamel specimens that were stressed in a direction parallel to prismatic orientation ${ }^{7}$, and it presented a compact structure without porosities. SEM observations of bleached specimens with carbamide peroxide-based agents containing fluoride or calcium showed sound patterns and little difference between groups containing fluoride or calcium and control groups. Unaffected enamel could maintain the strength, not altering its mechanical properties. No major differences were observed among the fluoride and calcium containing-bleaching agents.

Bleached fractured enamel with $10 \%$ carbamide peroxide (without fluoride and calcium) showed cone-like shape prisms with porous fractured ends. This can suggest evidences of the attack of the bleaching agents at the intraprismatic substance (Figure 3 ). It has been suggested that the porosities tend to be reduced when bleaching agents containing fluoride or calcium were applied (Figures 4 and 5).

Enamel treated with carbamide peroxide-based bleaching agents containing fluoride or calcium did not promote reduction of tensile strength. The presence of calcium and fluoride in peroxide carbamide gel impaired mineral loss usually promoted by bleaching. This fact can be related to supersaturation of the gels with calcium or fluoride. Moreover, these ions favor the remineralization or precipitation in intraprismatic structure.

Attin, et al. ${ }^{5}$ (2003) observed that both fluoridated or non-fluoridated gels, at acidic and neutral $\mathrm{pH}$, render the enamel more susceptible to demineralization. However, fluoridated neutral gels decrease mineral loss. In this current study, the $\mathrm{pH}$ was about 6.5 to 7.2 and it is not critical to hydroxyapatite demineralization. Indeed, as there was no statistical difference between storage in artificial saliva and $100 \%$ humid atmosphere, it seems that the effects observed were due to calcium and fluoride present in whitening products. Some studies proposed fluoride application after whitening procedures ${ }^{4,6}$, however, if it is possible to prescribe carbamide peroxide and fluoride or calcium in the same vial, it is easier to get better results. The lattice structure observed in the pictures show that maybe fluoride and calcium impaired demineralization or promoted remineralization.

It is generally agreed that the major effects of fluoride ion toward enhancing crystal growth and retarding dissolution of dental enamel minerals are derived from the contribution of fluoride ion in the solution phase to increase supersaturation or decrease undersaturation ${ }^{29}$. Fluoride is important not only to reduce the solubility of hydroxyapatite but also to precipitate products that are relevant on caries development ${ }^{28}$. Thus, it is pertinent to consider the relative ability of loosely bound fluoride to serve as reservoir sources.

The widespread use of bleaching procedures to whiten teeth for esthetic reasons increases the concerns about the safety of peroxide containing tooth whiteners on dental hard tissues. Even though no clinical reports about fractures or cracks of bleached dental enamel have been presented in dental literature, this in vitro study showed that a possible reduction in enamel strength might occur after carbamide peroxide bleaching. The clinical implications of carbamide peroxide-based whitening products containing fluoride or calcium must be further investigated.

\section{CONCLUSION}

The oxidizing effects of peroxide bleaching gels can render enamel weaker; however, the whitening treatment with $10 \%$ carbamide peroxide-based bleaching agents containing fluoride or calcium ions did not change the ultimate tensile strength of human enamel.

\section{ACKNOWLEDGEMENTS}

The authors are indebted to Dental Materials Laboratory (FOP-UNICAMP) for Universal Testing Machine support and to Dr. E.W. Kitajima (NAP-MEPA/ESALQ-USP) for technical electron microscopy support. The experimental bleaching materials used in this study were supplied by FGM Prod. Odontol. and are not commercially available This study was supported by grants 01/02771-7 and 02/04307-9 from FAPESP, Brazil.

\section{REFERENCES}

1- Akal N, Over H, Olmez A, Bodur, H. Effects of carbamide peroxide containing bleaching agents on the morphology and subsurface hardness of enamel. J Clin Pediatric Dent. 2001;25:293-6.

2- Arends J, Jongebloed W.L, Goldberg M, Schuthof J. Interaction of urea and human enamel. Caries Res. 1984;18:17-24.

3- Arwill T, Myberg N, Söremark R. Penetration of radioactive isotopes through enamel and dentin. Odontol Revy. 1969;20:47-54.

4- Attin T, Kielbassa AM, Schwanenberg M, Hellwig E. Effect of fluoride treatment on remineralization of bleached enamel. J Oral Rehabil. 1997;24:282-6.

5- Attin T, Kocabiyk M, Buchalla W, Hanning C, Becker K. Susceptibility of enamel surfaces to demineralization after application of fluoridated carbamide peroxide gels. Caries Res. 2003;37:93-9.

6- Burgmaier GM, Schulze IM, Attin T. Fluoride uptake and development of artificial erosions in bleached and fluoridated enamel in vitro. J Oral Rehabil. 2002;29:799-804.

7- Carvalho RM, Santiago SL, Fernandes CAO, Suh BI, Pashley DH. Effects of prism orientation on tensile strength of enamel. J Adhes Dent. 2000:2:251-7.

8- Cavalli V, Reis AF, Giannini M, Ambrosano GMB. The effect of elapsed time following bleaching on enamel bond strength of resin composite. Oper Dent. 2001;26:597-602.

9- Cavalli V, Arrais CAG, Giannini M. Scanning electron microscopy observations of human bleached enamel surface. Acta Microsc. 2001;1(supplement A):41-2. 
10- Cavalli V, Giannini M, Carvalho RM. Effect of carbamide peroxide bleaching agents on tensile strength of human enamel. Dent Mater. 2004;20:733-9.

11- Cimilli H, Pameijer $\mathrm{CH}$. Effect of carbamide peroxide bleaching agents on the physical properties and chemical composition of enamel. Am J Dent. 2001;14:63-6.

12- Flaitz CM, Hicks MJ. Effects of carbamide peroxide whitening agents on enamel surfaces and caries-like lesion formation: An SEM and polarized light microscopic in vitro study. ASDC J Dent Child. 1996;63:249-56.

13- Haywood VB, Heymann HO. Nightguard vital bleaching. Quintessence Inter. 1989;20:173-6.

14- Haywood VB, Robinson RG. Vital tooth bleaching with nightguard vital bleaching. Curr Opin Cosmet Dent. 1997;4:45-52.

15- Hegedüs C, Bistey T, Flóra-Nagy E, Keszthelyi G, Jenei A. An atomic force microscopy study on the effect of bleaching agents on enamel surface. J Dent. 1999;27:509-15.

16- Kelleher MG, Roe FJ. The safety-in-use of $10 \%$ carbamide peroxide (Opalescence) for bleaching teeth under the supervision of a dentist. Br Dent J. 1999;187:190-4.

17- Leonard Jr RJ, Eagle JC, Garland GE, Matthews KP, Rudd AL, Phillips C. Nightguard vital bleaching and its effect on enamel surface morphology. J Esthet Restor Dent. 2001;13:132-9.

18- Li I. Biological properties of peroxide-containing tooth whiteners. Food Chem Toxicol. 1996;34:887-904.

19- Markovic M, Sieck BA, Takagi S, Chow LC, Majeti S. Diffusion of hydrogen peroxide through sound enamel [abstract n. 1290]. J Dent Res. 2000;79(sp. Issue):305.

20- Murchison DR, Charlton DG, Moore BK. Carbamide peroxide bleaching: Effects on enamel suface hardness and bonding. Oper Dent. 1992;17:181-185

21- Nainar SM, Clarkson BH. Fluoride profile in mature unerupted enamel following removal of surface organic material. Caries Res. 1994;28:83-6.

22- Oltu Ü and Gürgan S. Effects of three concentrations of carbamide peroxide on the structure of enamel. J Oral Rehabil. 2000;27:332 40

23- Perdigão J, Francci C, Swift Jr EJ, Ambrose WW, Lopes M. Ultramorphological study of the Interaction of dental adhesives with carbamide peroxide-bleached enamel. Am J Dent. 1998;11:291-301.

24- Potocnik I, Kosec L, Gaspersic D. Effect of $10 \%$ carbamide peroxide bleaching gel on enamel microhardness, microstructure, and mineral content. J Endod. 2000;26:203-6.

25- Rotstein I, Dankner E, Goldman A, Heling I, Stabholz A, Zalkind M. Histochemical analysis of dental hard tissues following bleaching. J Endod. 1996;22:23-6.

26- Seghi RR, Denry I. Effects of external bleaching on indentation and abrasion characteristics of human enamel. J Oral Rehabil. 1992; $71: 1340-44$

27- Shannon H, Spencer P, Gross K and Tira D. Characterization of enamel exposed to $10 \%$ carbamide peroxide bleaching agents. Quintessence Inter. 1993;24:39-44.

28- Ten Cate JM, Van Loveren C. Fluoride mechanisms. Dent Clin North Am. 1999;43:713-42.
29- White DJ, Nancollas GH. Physical and chemical considerations of the role of firmly and loosely bound fluoride in caries prevention. J Dent Res. 1990;69(sp. n. 587-94):634-6. 